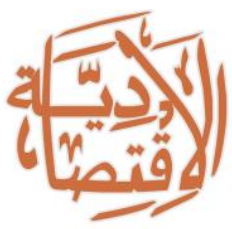

\title{
ASPEK HUKUM QARDH PADA PEMBIAYAAN TAKE OVER (Analisis Fatwa DSN-MUI Nomor 31 Tahun 2002 Tentang Pengalihan Utang)
}

\author{
Rahmatul Huda' ${ }^{1}$ Zakiyah ${ }^{2}$ \\ Fakultas Studi Islam, Universitas Islam Kalimantan Muhammad Arsyad al-Banjari, Indonesia. E-mail: \\ hoeda.errahmah@gmail.com ${ }^{1}$; kikiayoenani@yahoo.com ${ }^{2}$
}

\section{ARTICLE INFO}

Keywords:

Legal Aspects; Qardh; Take Over.

\section{Kata Kunci:}

Aspek Hukum; Qardh; Take Over.

\section{ABSTRACT}

This study aims to explain the legal aspects of qard on take over financing and analyze it based on the Fatwa DSN-MUI Number 31 of 2002 concerning Debt Transfer. This research is a normative legal research, because this research is a study of legal principles and statutory regulations related to the qardh contract on take-over financing products. Based on the research conducted, the results of this study indicate that the provision of qardh services for taking over the customer's principal debt plus the interest is due to the use of unlimited qardh, including to bail out interest-based debt, so that the provision of qardh services is more appropriate for transferring customer debt from conventional banking to islamic banking. Based on the results of the analysis of the Fatwa DSN-MUI Number 31 of 2002, the most suitable alternative to be applied in take over financing is the third alternative, namely using a combination of ijarah and qardh contracts. Because the third alternative is the simplest form and easiest to implement. However, keeping in mind that the amount of ujrah is determined based on real expenditure, not on the amount of debt given by the LKS.

\section{ABSTRAK}

Penelitian ini bertujuan untuk menjelaskan aspek hukum qard pada pembiayaan take over dan menganalisisnya berdasarkan Fatwa DSNMUI Nomor 31 Tahun 2002 Tentang Pengalihan Utang. Adapun penelitian ini merupakan penelitian hukum normatif, karena penelitian ini kajiannya mengenai kaidah-kaidah hukum dan peraturan perundang-undangan yang berkaitan dengan akad qardh pada produk pembiayaan take over. Berdasarkan penelitian yang dilakukan, maka hasil penelitian ini menunjukkan bahwa pemberian jasa qardh pada pengambilalihan utang pokok nasabah ditambah bunganya dikarenakan penggunaan qardh tidak terbatas, termasuk untuk menalangi utang yang berbasis bunga, sehingga pemberian jasa qardh lebih tepat untuk mengalihkan utang nasabah di bank konvensional ke bank syariah. Berdasarkan hasil analisis terhadap Fatwa Dewan Syariah Nasional Nomor 31/DSNMUI/VI/2002, maka alternatif yang paling cocok untuk diterapkan dalam pembiayaan take over adalah alternatif ketiga yaitu menggunakan kombinasi akad ijarah dan qardh. Karena alternatif ketiga merupakan bentuk yang paling sederhana dan mudah untuk diimplementasikan. Namun dengan tetap memperhatikan bahwa besarnya ujrah ditentukan berdasarkan pengeluaran riil, bukan pada besarnya utang yang diberikan oleh LKS. 


\section{Pendahuluan}

Islam adalah agama yang universal dan komprehensif, mencakup seluruh aspek kehidupan manusia. Syariat yang mengatur hubungan antara manusia dengan Tuhannya, disebut dengan ibadah. Dan juga syariat yang mengatur hubungan antar sesama manusia disebut dengan mu'amalah. Aturan kompleks dan lengkap dari Allah SWT sebagai tuntunan bagi hamba-Nya dalam menjalani kehidupan dunia sebaik-baiknya. Kegiatan ekonomi tidak bisa dipisahkan dari kehidupan manusia, karena terkait dengan kebutuhan dan keinginan manusia dalam pemenuhan hajat hidup. Kegiatan ekonomi merupakan bagian dari mu'amalah.

Ekonomi Islam mulai muncul pada tahun 90-an di Indonesia. Hal tersebut ditandai dengan berdirinya bank berbasis syariah yang dipelopori oleh Bank Muamalat Islam (BMI). Saat ini perkembangan ekonomi Islam sangat pesat, ditandai dengan berdirinya lembaga perbankan dan lembaga-lembaga keuangan Islam non bank lainnya.

Peran perbankan syariah saat ini sangat diperhitungkan, sehingga bank syariah mengalami perkembangan yang cukup pesat. Bank tidak hanya sebagai tempat menabung saja tetapi juga berlomba memberikan layanan yang langsung menyentuh kebutuhan transaksi masyarakat. Salah satu produk perbankan syariah yang ditawarkan adalah pembiayaan take over, yaitu sebelumnya nasabah memiliki pinjaman di bank konvensional. Biasanya pembiayaan take over ini diaplikasikan pada bidang kredit kepemilikan rumah (KPR). Produk-produk yang ditawarkan oleh perbankan syariah tersebut haruslah sesuai dengan prinsip syariat Islam, yaitu tidak mengandung riba, gharar, dan maisir. Untuk itu perlu dibahas dan dikritisi tentang aspek hukum qardh dalam pembiayaan take over. Berdasarkan latar belakang tersebut, maka rumusan masalah pada penelitian ini adalah: (1) Bagaimana aspek hukum qard pada pembiayaan take over? (2) Bagaimana analisis Fatwa DSN-MUI Nomor 31 Tahun 2002 Tentang Pengalihan Utang terhadap pembiayaan take over?

Berdasarkan penelusuran yang telah penulis lakukan, ada beberapa artikel jurnal yang membahas tentang take over diantaranya artikel yang ditulis oleh Dhaifina Fitriani dengan judul "Griya Take Over Dalam Perbankan Syariah (Studi Kasus PT. Bank BNI Syari'ah Kantor Cabang Yogyakarta. Artikel ini membahas tentang praktik pengalihan hutang (take over) di PT. Bank BNI Syari'ah Kantor Cabang Yogyakarta yang menggunakan akad murabahah karena pihak bank (sebagai penanggung hutang/kreditur kedua) membeli jaminan nasabah pada bank sebelumnya sesuai dengan sisa hutangnya. ${ }^{1}$ Artikel yang ditulis oleh Zaky, Achmad, dengan judul Analisis Alternatif Pembiayaan Take Over Berdasarkan Prinsip Syariah (Hawalah), Artikel ini membahas tentang kesesuaian karakteristik akad dan prinsip syariah, serta implikasi perlakuan akuntansi masingmasing alternatif yang ditawarkan oleh Fatwa DSN MUI

\footnotetext{
${ }^{1}$ Dhaifina Fitriani, Griya Take Over Dalam Perbankan Syariah (Studi Kasus PT. Bank BNI Syari'ah Kantor Cabang Yogyakarta), Jurnal Az Zarqa', Vol.12 No.1, 2020
} 
Jurnal Ekonomi Syariah dan Hukum Ekonomi Syariah

Nomor: 31/DSN-MUI/VI/2002 tentang pengalihan hutang. ${ }^{2}$ Artikel yang ditulis Anggraini, Juwita, dan Siti Mardiah, dengan judul Analisis Kinerja Pembiayaan Take Over Pada BTN Syariah Di Tahun 2014-2015, Artikel ini membahas tentang perlambatan pertumbuhan pembiayaan pada tahun 2014 mendorong pemerintah untuk merevisi kebijakan Financing To Value dan uang muka pembiayaan properti dan juga penerapan PBI no17/10/PBI/2015 pada pembiayaan Take Over memiliki pengaruh positif yang signifikan baik secara kualitas maupun kuantitas pembiayaan. ${ }^{3}$ Artikel yang ditulis Distie Saraswati dan Syamsul Hidayat dengan judul Implementasi Hybrid Contract Pada Take Over Pembiayaan Hunian Syariah Dari Bank Konvensional Ke Bank Syariah Dalam Perspektif Hukum Islam, Artikel ini membahas tentang Proses take over yang dilakukan oleh bank syariah ke bank konvensional dengan sistem syirkah al-milk, lalu memberikan produk pembiayaan hunian syariah kepada nasabah dengan akad ba'i murabahah tidak dapat dimasukkan ke dalam hybrid contracts yang dilarang dalam perspektif Hukum Islam. ${ }^{4}$

Berdasarkan penelusuran tersebut maka penelitian ini berbeda dengan penelitianpenelitian terdahulu karena riset ini berfokus pada aspek hukum qard pada pembiayaan take over kemudian menganalisisnya berdasarkan Fatwa DSN-MUI Nomor 31 Tahun 2002 Tentang Pengalihan Utang, yang mana pembahasan ini belum dibahas dalam penelitian terdahulu.

\section{Kajian Teoritis}

\subsection{Tinjauan Umum tentang Qardh}

Qardh merupakan suatu pemberian harta terhadap orang dan harta tersebut dapat ditagih kembali. Qardh Dalam literatur figh Salafl-Shalih, termasuk dalam 'aqd tathawwui (akad saling membantu), bukan transaksi komersial. ${ }^{5}$ Syafi'i Antonio berpendapat bahwa qardh merupakan pemberian harta yang mana harta tersebut dapat ditagih kembali atau dapat pula diistilahkan dengan meminjamkan tanpa mengharap imbalan. Qardh menurut Bank Indonesia merupakan suatu akad pinjaman yang berasal dari bank (muqridh) terhadap pihak tertentu (muqtaridh) yang mana wajib dikembalikan sesuai jumlah yang dipinjam. ${ }^{6}$ Akad qardh sebagai akad pinjam meminjam dana tanpa ada persyaratan tambahan apapun. ${ }^{7}$ Akad qardh

\footnotetext{
${ }^{2}$ Achmad Zaky, Analisis Alternatif Pembiayaan Take Over Berdasarkan Prinsip Syariah (Hawalah), Jurnal Ekonomi, Manajemen, dan Akuntansi Islam (IMANENSI), Vol.1 No.2, 2014

3Juwita Anggraini, dan Siti Mardiah, Analisis Kinerja Pembiayaan Take Over Pada BTN Syariah Di Tahun 2014-2015, Jurnal Finance, Vol.2 No.1, 2016

${ }^{4}$ Distie Saraswati, dan Syamsul Hidayat, Implementasi Hybrid Contract Pada Take Over Pembiayaan Hunian Syariah Dari Bank Konvensional Ke Bank Syariah Dalam Perspektif Hukum Islam, Jurnal Jurisprudence, Vol.7 No.1, 2017

${ }^{5}$ Siti Nor Fatoni, Pengantar IImu Ekonomi, Dilengkapi Dasar-Dasar Ekonomi Islam, (Bandung: Pustaka Setia, 2014), h. 221

${ }^{6}$ Sunarto Zulkifli, Panduan Praktis Transaksi Perbankan Syariah, (Jakarta: Zikrul Hakim, 2003), h. 27

${ }^{7}$ Nurhayati, Sri Wasilah, Akuntansi Syariah di Indonesia, (Jakarta: Salemba Empat, 2013)
} 
adalah transaksi pinjam meminjam dana tanpa imbalan dengan kewajiban pihak peminjam mengembalikan pokok pinjaman secara sekaligus atau cicilan dalam jangka waktu tertentu. ${ }^{8}$ Jadi dapat disimpulkan bahwa qardh adalah suatu pemberian harta kepada orang lain yang dapat ditagih/diminta kembali dengan jumlah yang sama sesuai dengan pinjaman.

Para ulama tidak ada perbedaan pendapat mengenai dasar hukum qardh. Dasar hukumnya adalah boleh dan dibenarkan secara syariat. Dalil hukum yang berkaitan dengan qardh meliputi:

a. Al-Qur'an

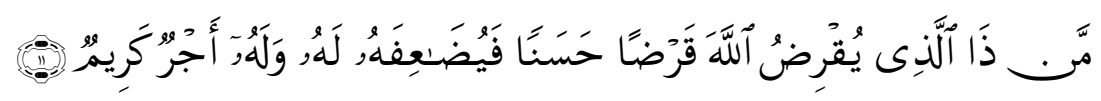

Artinya: "Siapakah yang mau meminjamkan kepada Allah pinjaman yang baik, Maka Allah akan melipat-gandakan (balasan) pinjaman itu untuknya, dan Dia akan memperoleh pahala yang banyak." (Q.S. al-Ḥadîd [57]: $11)^{9}$

b. Hadis

$$
\text { ما من مسلم يقرض مسلما قرضا مر تين إلا كان كصد قتها مرة }
$$

Artinya: Ibnu Mas'ud meriwayatkan bahwa Nabi Muhammad saw. berkata, "Bukan seorang muslim (mereka) yang meminjamkan (kepada) muslim (lainnya) dua kali yang satunya adalah (senilai) sedekah." (H.R. Ibnu Majah, No. 2421, Kitab Al-Ahkam-Ibnu Hibban, dan Baihaqi)

c. Ijma'

Pinjam meminjam sudah menjadi bagian dari kehidupan, termasuk dalam kehidupan umat Islam. Para ulama sepakat bahwa qardh boleh dilakukan. Menurut para ulama bahwa manusia memiliki tabiat yang tidak bisa hidup tanpa pertolongan dari saudaranya. Islam adalah agama yang sangat memperhatikan segenap kebutuhan umatnya. Sebagaimana konsep bahwa manusia adalah makhluk sosial. Manusi membutuhkan manusia lainnya, termasuk dalam pertolongan pinjam-meminjam harta ${ }^{10}$

Di dalam utang-piutang terdapat rukun dan syarat di dalamnya, meliputi:

a. Muqridh, pihak pemberi utang kepada pihak lain yang membutuhkan. Ketentuannya adalah sudah dewasa, sehat akalnya, dan tidak terhalang untuk melakukan perbuatan hukum itu.

\footnotetext{
${ }^{8}$ Muhamad, Manajemen Dana Bank Syariah, (Jakarta: Rajawali Pers, 2015), h. 54

${ }^{9}$ Departemen Agama RI, Al-Qur'an dan Terjemahnya, (Bandung: Diponegoro, 2008), h. 538

${ }^{10}$ Muhammad Syafi'i Antonio, Bank Syariah: Dari Teori Ke Praktik, (Jakarta: Gema Insani Press, 2001), h. 133
} 
b. Muqtaridh, pihak yang berhutang atau membutuhkan pinjaman. Sebagaimana muqridh, ia juga harus cakap melakukan perbuatan hukum.

c. Al-ma'qûd 'alaih, yaitu objek utang-piutang, di dalamnya da syarat atau ketentuan yang diketahui secara pasti berapa nilainya.

d. shîghah, dapat diartikan sbagai lafadz, yaitu adanya pernyataan baik dari pihak yang mengutangkan maupun pihak yang akan menerimanya. ${ }^{11}$

Utang-piutang akan sah manakala terpenuhi rukun dan syaratnya. Maka jika syart tersebut di atas tidak terpenuhi, maka dalam praktinya terdapat kesalahan yang mengakibatkan dilarangnya secara hukum.

Qardh merupakan bagian dalam kehidupan sehari-hari. Di dalamnya ada nilai tolongmenolong. Qardh dalam di perbankan syariah diterapkan pada:

a. Pinjaman atau Dana Talangan Haji, ini diberikan oleh bank kepada nasabah calon haji. Di dalamnya terdapat dua akad, yaitu qardh atau pinjma-meminjam dan akad ijarah atau jual beli jasa.

b. Cash Advanced atau berupa pinjaman tunai produk kartu kredit syariah, nasabah diberi keleluasaan menarik uangnya secara tunai melalui ATM, di samping itu nasabah akan mengembalikannya sesuai dengan waktu yang sudah ditentukan.

c. Bantuan pinjaman dana kepada para pengusaha kecil, dalam hal ini menurut perhitungan bank akan memberatkan si pengusaha apabila diberikan pembiayaan dengan menerapkan skema jual beli maupun bagi hasil.

d. Pemberian pinjaman kepada nasabah dengan kriteria bahwa nasabah tersebut memerlukan dana cepat sedangkan ia dalam keadaan tidak bisa menarik dananya (faktor dana tersimpan berupa deposito).

e. Bank menyediakan pinjaman kepada pengurus bank. Bantuan ini bertujuan untuk memastikan sudah terpenuhinya kebutuhan para pengurus bank, dan mereka nantinya akan megembalikannya bertahap melalui pemotongan gaji. ${ }^{12}$

Akad qardh dalam Lembaga Keuangan Syariah terdiri atas dua macam. Hal ini berdasarkan pada Fatwa DSN No. 79/DSN-MUI/III/2011:13

a. Akad yang bertujuan untuk tujuan sosial. Akad ini berdiri sendiri. Akad ini seuai dengan fatwa DSN-MUI Nomor: 19/DSN-MUI/IV/2001 tentang al-Qardh;

b. Akad yang dilakukan sebagai sarana atau kelengkapan bagi transaksi lain dengan menggunakan akad mu'awadhah (pertukaran dan dapat bersifat komersial), artinya ini untuk mendapatkan keuntungan. Akad atau produk yang dimaksud

\footnotetext{
${ }^{11}$ Abdul Ghofur Anshori, Pokok-pokok Hukum Perjanjian Islam di Indonesia, op.cit., h. 127-128

${ }^{12}$ Muhammad Nor Abdi, Praktek Al-Qardh di Perbankan Syariah, https://muhammadnorabdi.wordpress.com/2011/08/06/19/. Diakses pada 25 Februari 2019.

${ }^{13}$ Majelis Ulama Indonesia, Himpunan Fatwa Keuangan Syariah; Dewan Syariah Nasional MUI, (Jakarta: Erlangga, 2014), h. 453-454
} 
misalnya rahn emas, pengalihan utang, syariah charge card, pembiayaan pengurusan haji Lembaga Keuangan Syariah, syariah card, anjak piutang syariah.

Persyaratan penerapan akad qardh yang berdiri sendiri untuk tujuan sosial semata, tidak boleh menggunakan dana nasabah. Sedangkan akad yang bertujuan untuk mendapatkan keuntungan, diperbolehkan menggunakan dana nasabah. Sehingga keuntungan atau pendapatan dari akad atau produk yang menggunakan mu'awadhah yang dilengkapi dengan akad qardh, harus dibagikan kepada nasabah penyimpan dana sesuai akad yang dilakukan.

\subsection{Pembiayaan Take Over}

Secara etimologi take over berarti mengambil alih. ${ }^{14}$ Ahmad Antoni K. Muda, mendefinisikan take over sebagai suatu tindakan pengambilalihan yang terjadi dalam suatu perusahaan. Dalam perusahaan take over tersebut adalah perubahan kepentingan pengendalian suatu perseroan. ${ }^{15}$ Eti Rochaety dan Ratih Tresnati berpendapat bahwa take over disamping adanya suatu kepentingan dalam pengendalian pada perseroan, take over juga memiliki definisi sebagai tindakan pengambilalihan perusahaan lain. ${ }^{16}$ Selanjutnya Menurut T. Guritno, take over merupakan tindakan mengambil alih sesuatu. Take over dalam lingkup perseroan berati berupa penawaran kepada pihak pemegang saham untuk membeli sahamnya, baik seluruhnya maupun sebagian dengan ketentuan harga tertentu dan dengan tujuan menguasai perseroan yang ditawar. Istilah take over dalam perusahaan menunjukkan bahwa pada awalnya terdapat keberatan yang berasal dari pemilik maupun perseroan yang umumnya lebih besar dari yang ditawar. ${ }^{17}$ Berdasakan pendapat di atas, dapat digambarkan bahwa take over yang dilakukan dalam lingkup usaha (bisnis), adalah suatu cara pengambilalihan kendali atas suatu usaha (bisnis).

Pembiayaan berdasarkan take over adalah pembiayaan yang timbul sebagai akibat dari take over terhadap transaksi nonsyariah yang telah berjalan yang dilakukan oleh bank syariah atas permintaan nasabah. ${ }^{18}$ Adapun take over yang dimaksud peneliti dalam jurnal ini adalah take over dalam konsep Fatwa Dewan Syariah Nasional Nomor 31/DSNMUI/VI/2002, yaitu take over dengan makna pengalihan utang. Take over dalam pemaparan ini adalah pengalihan transaksi nonsyariah yang telah berjalan menjadi transaksi yang sesuai dengan syariah. Atau dengan kata lain pengalihan dari bank konvensional menjadi pebiayaan dengan prinsip jual beli yang berdasarkan syariah.

\footnotetext{
${ }^{14}$ John M. Echols dan Hassan Shadily, Kamus Inggris Indonesia, (Jakarta: PT. Gramedia Pustaka Utama, 1990), h. 578

${ }^{15}$ Ahmad Antoni K. Muda, Kamus Lengkap Ekonomi, (Jakarta: Gitamedia Press, 2003), h. 331

${ }^{16}$ Ety Rochaety dan Ratih Tresnati, Kamus Istilah Ekonomi, (Jakarta: PT. Bumi Askara, 2005), h. 331

${ }^{17}$ T. Guritno, Kamus Perbankan dan Bisnis, (Yogyakarta: UGM Press, 1996), h. 298

${ }^{18}$ Adiwarman A. Karim, Bank Islam: Analisis Fiqih dan Keuangan, (Jakarta: RajaGrafindo, 2011)Cet.8, h. 248
} 
Bank syariah dalam proses take over bertindak sebagai pihak yang akan membantu calon nasabahnya untuk melunasi sisa kredit yang terdapat di bank asal, mengambil bukti lunas, surat asli agunan, perizinan, polis asuransi, dan surat roya, sehingga barang (dalam hal ini sebagai contoh adalah rumah) menjadi milik nasabah secara utuh. Dalam hal pelunasan hutang kepada bank syariah, maka nasabah menjual kembali rumahnya kepada bank syariah. Selanjutnya bank syariah akan menjual rumah tersebut lagi kepada nasabah dengan pilihan kombinasi akad yang tertera dalam fatwa DSN-MUI/VI/2002 tentang pengalihan utang seperti qardh dan murabahah, syirkah al-milk dan murabahah, ${ }^{19}$ qardh dan ijarah, serta qardh dan ijarah muntahiyah bi-tamlik (IMBT).

Adapun landasan syariah dari pelaksanaan take over, yaitu:

a. Al-Qur'an

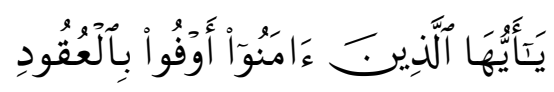

Artinya: "Hai orang-orang yang beriman, penuhilah aqad-aqad itu..." (Q.S. alMa'idah [5]:1) 20
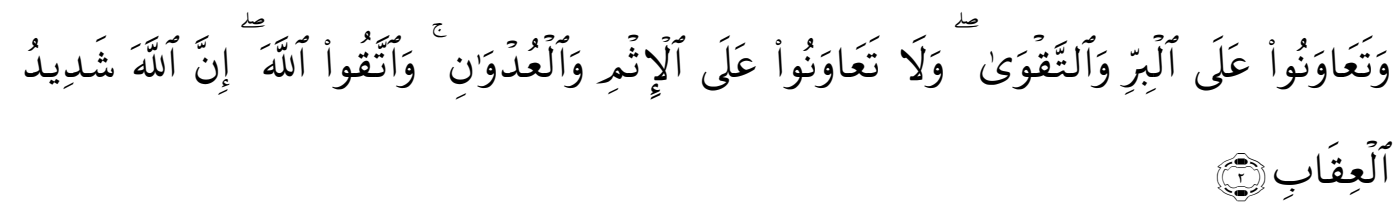

Artinya: “...dan tolong-menolonglah kamu dalam (mengerjakan) kebajikan dan takwa, dan jangan tolong-menolong dalam berbuat dosa dan pelanggaran. dan bertakwalah kamu kepada Allah, Sesungguhnya Allah Amat berat siksa-Nya." (Q.S. al-Ma'idah [5]:2)21

b. Hadis

Riwayat dari Imam al-Tirmidzi dari 'Amr bin 'Auf al-Muzani, Nabi s.a.w. bersabda dalam hadisnya:

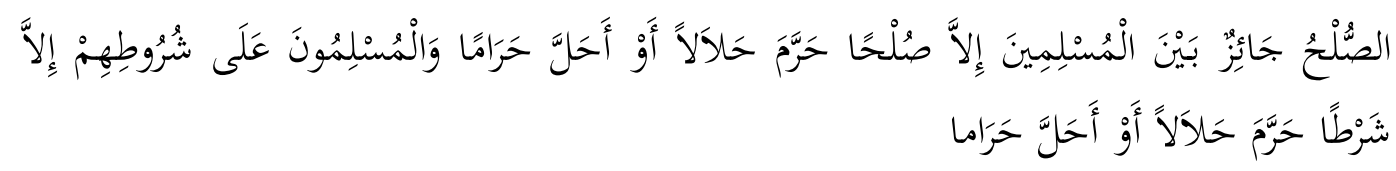

Artinya: "Perjanjian boleh dilakukan di antara kaum muslimin kecuali perjanjian yang mengharamkan yang halal atau menghalalkan yang haram; dan

\footnotetext{
${ }^{19}$ Murabahah adalah jual beli yang harga pokok dan jualnya diketahui dengan jelas oleh para pihak. Murabahah termasuk dalam kategori natural certainty contract, karena keuntungannya sudah jelas terlihat dari awal akad. Lihat Muhammad Rifqi Hidayat dan Parman Komarudin, "Klausul Overmacht dalam Akad Murabahah di Perbankan Syariah," Al-Iqtishadiyah: Ekonomi Syariah dan Hukum Ekonomi Syariah 3, no. 1 (2017): 39.
}

${ }^{20}$ Departemen Agama RI, Al-Qur'an dan Terjemahnya, op.cit., h. 106

${ }^{21}$ lbid., h. 106 
kaum muslimin terikat dengan syarat-syarat mereka kecuali syarat yang mengharamkan yang halal atau menghalalkan yang haram."

c. Kaidah Fiqh

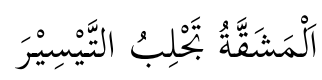

Artinya: "Kesulitan dapat menarik kemudahan."

Take over merupakan salah satu bentuk jasa pelayanan keuangan yang menjadi kebutuhan masyarakat. Take over bertujuan untuk membantu masyarakat untuk mengalihkan transaksi non syariah yang telah berjalan menjadi transaksi yang sesuai syariah. Bank syariah membantu memfasilitasi masyarakat dalam memindahkan transaksinya agar berjalan sesuai dengan hukum Islam, dengan demikian transaksi ini dapat memberikan kebaikan di dunia dan di akhirat kelak.

Dalam hal Kredit Pemilikan Rumah (KPR), take over nasabah di suatu bank dapat terjadi apabila: ${ }^{22}$

a. Terjadi fluktuasi suku bunga pada bank konvensional yang mengakibatkan angsuran KPR nasabah tidak menentu. Umumnya sifat penawaran KPR bank konvensional terbagi menjadi dua jenis, yaitu bunga kredit baru dan bunga kredit berjalan. Perbedaan antara bunga kredit baru dan berjalan adalah mengenai masa waktunya. Bunga kredit baru ditetapkan lebih rendah dengan jangka waktu tertentu, misalnya fixed 1 tahun pertama atau fixed 5 tahun pertama. Sedangkan ketika lewat masa fixed, bunga akan disesuaikan dengan kondisi pasar. Bunga pada umumnya diriview setiap keadaan ini dapat mengakibatkan angsuran nasabah bersifat fluktuatif khususnya apabila terjadi krisis ekonomi. Sebaliknya keadaan ini dapat menguntungkan nasabah pada bank syariah karena sistem yang diapakai adalah jual beli di mana keuntungan bank telah ditetapkan di awal perjanjian.

b. Adanya pemikiran dan pemahaman dari nasabah bahwa penerapan sistem bunga bank tidak halal. Dalam syariat diajarkan bahwa ketika seseorang meminjamkan sesuatu maka tidak boleh mengambil imbalan atas pinjaman tersebut, dalam jumlah sedikit maupun banyak. Sistem pada bank konvensional, dana yang masuk diputar dengan cara dipinjamkan terhadap pihak lain dan mendapat untung dalam bentuk bunga. ${ }^{23}$ Penetapan jumlah bunga ini tanpa adanya pertimbangan resiko rugi yang bisa saja terjadi terhadap nasabah. ${ }^{24}$ Bunga dibebankan pada pinjaman yang diberikan pada kredit konsumtif. Apabila terjadi kemacetan dalam membayarkan angsuran, maka bunga yang dibebankan menjadi berlipat ganda.

\footnotetext{
${ }^{22}$ Anggun Dineey, Take Over Syariah, http://anggundineey17.blogspot.com/2012/12/bab-ipendahuluan-a.html. Diakses pada 25 Febriari 2015.

${ }^{23}$ Rahmat Firdaus dan Maya Arianti, Manajemen Perkreditan Bank Umum: Teori, Masalah, Kebijakan, dan Aplikasi Lengkap dengan Analisis Kredit, (Bandung: Alvabeta, 2004), h. 83-86

${ }^{24}$ Ibid., h. $88-89$
} 
c. Keterkaitan mengenai pembayaran angsuran pada awal tahun perjanjian ternyata sebagian besar untuk membayar bunga dan pokoknya sedikit sekali mengakibatkan outstanding pokok KPR turunnya tidak signifikan. Hal ini dapat menegcewakan nasabah. ${ }^{25}$ Beda halnya dengan ban syariah, dimana angsuran pokok dan margin berimbang, sehingga penurunan outstanding pokok KPR signifikan. Berimbang yang dimaksud bukan berarti 50:50, tetapi terlihat adanya penurunan outstanding pokok pada KPR bank syariah lebih signifikan dibandingkan bank konvensional.

Take over memiliki persyaratan sebagaimana persyaratan yang terjadi pada bank umumnya. take over yang diajukan pada bank syariah kepada calon nasabahnya pada kreditnya di bank konvensional sama dengan nasabah yang ingin mengajukan pembiayaan baru di bank syariah. Persyaratan tersebut misalnya batas usia maksimal pelunasan pembiayaan, batas usia minimum pengajuan pembiayaan, batas minimal masa kerja, dan memenuhi syarat-syarat berdasarkan penilaian oleh bank.

Dalam rangka melakukan penilaian, bank melakukan peninjaun lapangan untuk memastikan keadaan objek pembiayaan. Pada tahap selanjuynya, jika pengajuan disetujui, maka pihak perwakilan dari bank syariah, notaris, dan calon nasabah yang akan di take over kreditnya bertemu dengan perwakilan bank asal di tempat yang telah disepakati. Selanjutnya pihak bank syariah akan melunasi sisa kredit calon nasabah pada bank asal, baik cash maupun dengan cara transfer bank. Agunan akan diambil bank syariah setelah sisa kredit dilunasi. Bank asal akan melepas hak tanggungan atas barang yang di take over (dalam hal ini rumah) dengan mengeluarkan surat roya dan bank syariah akan mendaftarkan kembali agunan tersebut di badan pertanahan nasional (BPN). Setelah proses pelunasan selesai dilakukan, maka selanjutnya adalah dilakukan akad jual beli yang akan mengikat nasabah dengan bank syariah dengan menggunakan akad ijarah muntahiyyah bitamlik (IMBT).

\section{Pembahasan}

Fatwa DSN No. 31/DSN-MUI/VI/2002 tentang Pengalihan Utang, ${ }^{26}$ digambarkan dengan beberapa alternatif, meliputi:

\section{a. Alternatif I}

Pada alternatif pertama ini yang digunakan adalah akad qardh dan murabahah. Ilustrasinya adalah nasabah memiliki aset secara penuh dengan pemberian qardh dari LKS, sehingga nasabah dapat melunasi utangnya di LKK. Aset yang telah menjadi milik nasabah tersebut dijual kepada LKS dan dengan hasil penjualan itu nasabah dapat melunasi qardh-nya kepada LKS. Kemudian aset

\footnotetext{
${ }^{25}$ Muh Zuhri, Riba dalam Al-Qur'an dan Masalah Perbankan: Sebuah Tilikan Antisipasi, (Jakarta: PT RajaGrafindo Persada, 1996), h. 167

${ }^{26}$ Dewan Syariah Nasional Majelis Ulama Indonesia, Himpunan Fatwa Dewan Syariah Nasional, (Jakarta: Gaung Persada Press, 2012), h. 166-167
} 
yang telah menjadi milik LKS tersebut dijual kepada nasabah menggunakan akad murabahah, dengan pembayaran secara cicilan.

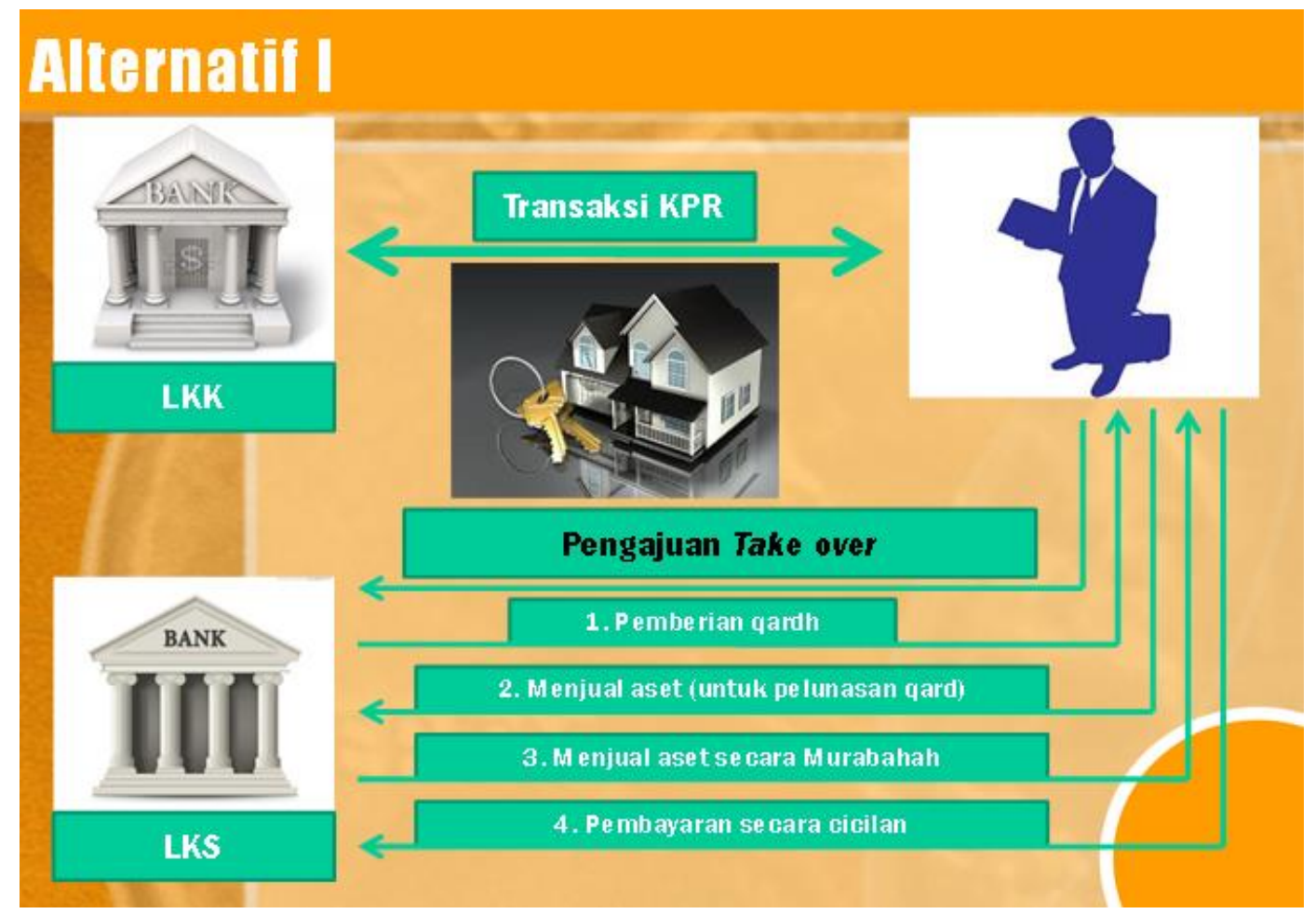

Gambar 1. Alternatif I untuk Akad Pengalihan Utang (Take Over)

b. Alternatif II

Pada alternatif kedua ini yang digunakan adalah akad syirkah al-milk dan murabahah. Ilustrasinya adalah dengan izin LKK, aset nasabah tersebut dibeli oleh LKS sehingga terjadi syirkah al-milk di antara mereka. Kemudian bagian aset yang telah dibeli oleh LKS tersebut dijual kepada nasabah menggunakan akad murabahah, dengan pembayaran secara cicilan. 


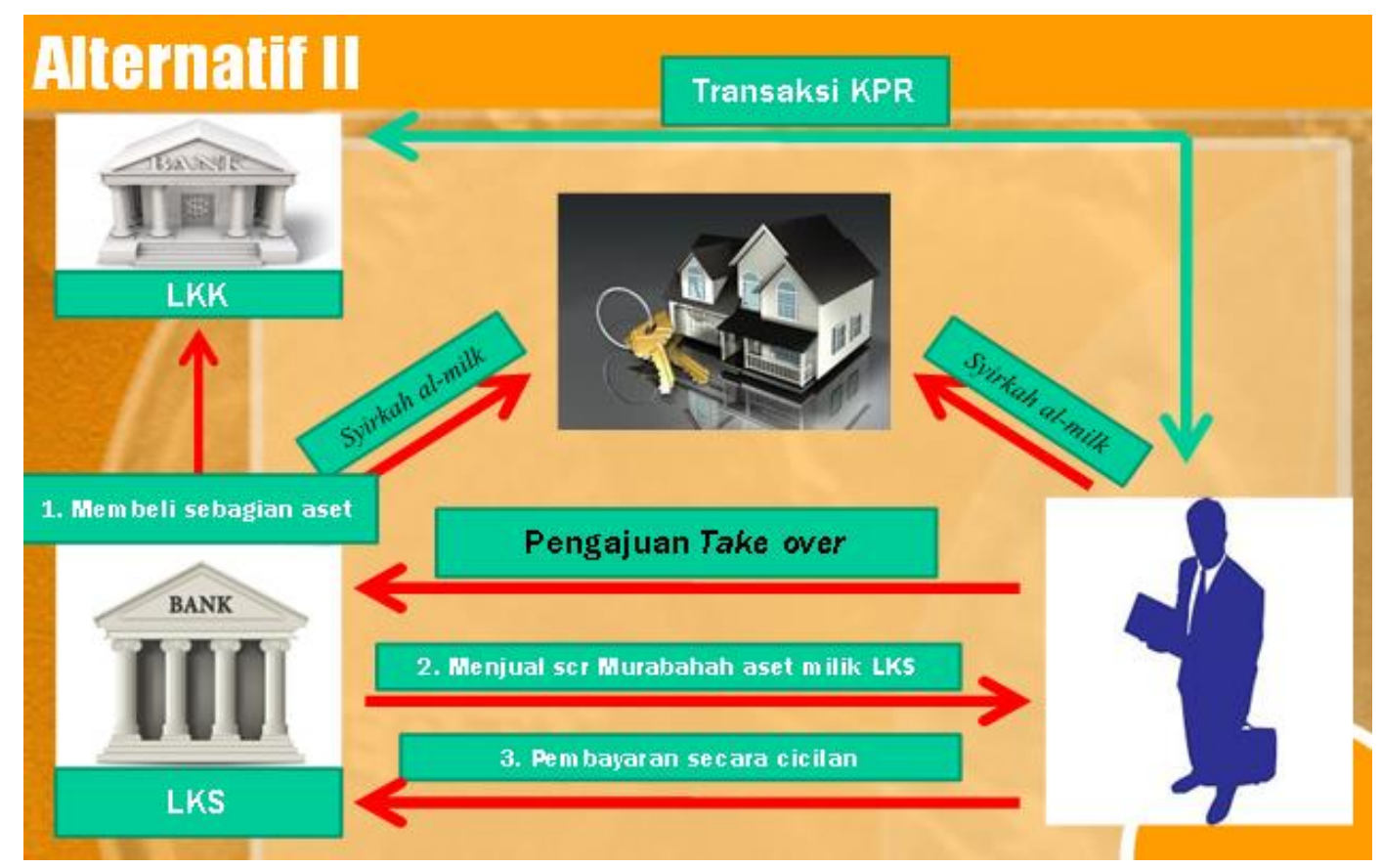

Gambar 2. Alternatif II untuk Akad Pengalihan Utang (Take Over)

c. Alternatif III

Pada alternatif ketiga ini yang digunakan adalah akad ijarah dan qardh. Ilustrasinya adalah LKS menguruskan agar nasabah dapat memperoleh kepemilikan aset secara penuh dengan menggunakan akad ijarah. Dalam hal pengurusan kepemilikan aset ini, jika diperlukan LKS dapat memberikan talangan atas utang nasabah di LKK dengan menggunakan akad qardh. Yang perlu diperhatikan bahwa imbalan jasa ijarah tersebut besarannya tidak boleh didasarkan pada jumlah talangan dan akad ijarah tersebut harus terpisah dari akad qardh (tidak boleh dipersyaratkan). 


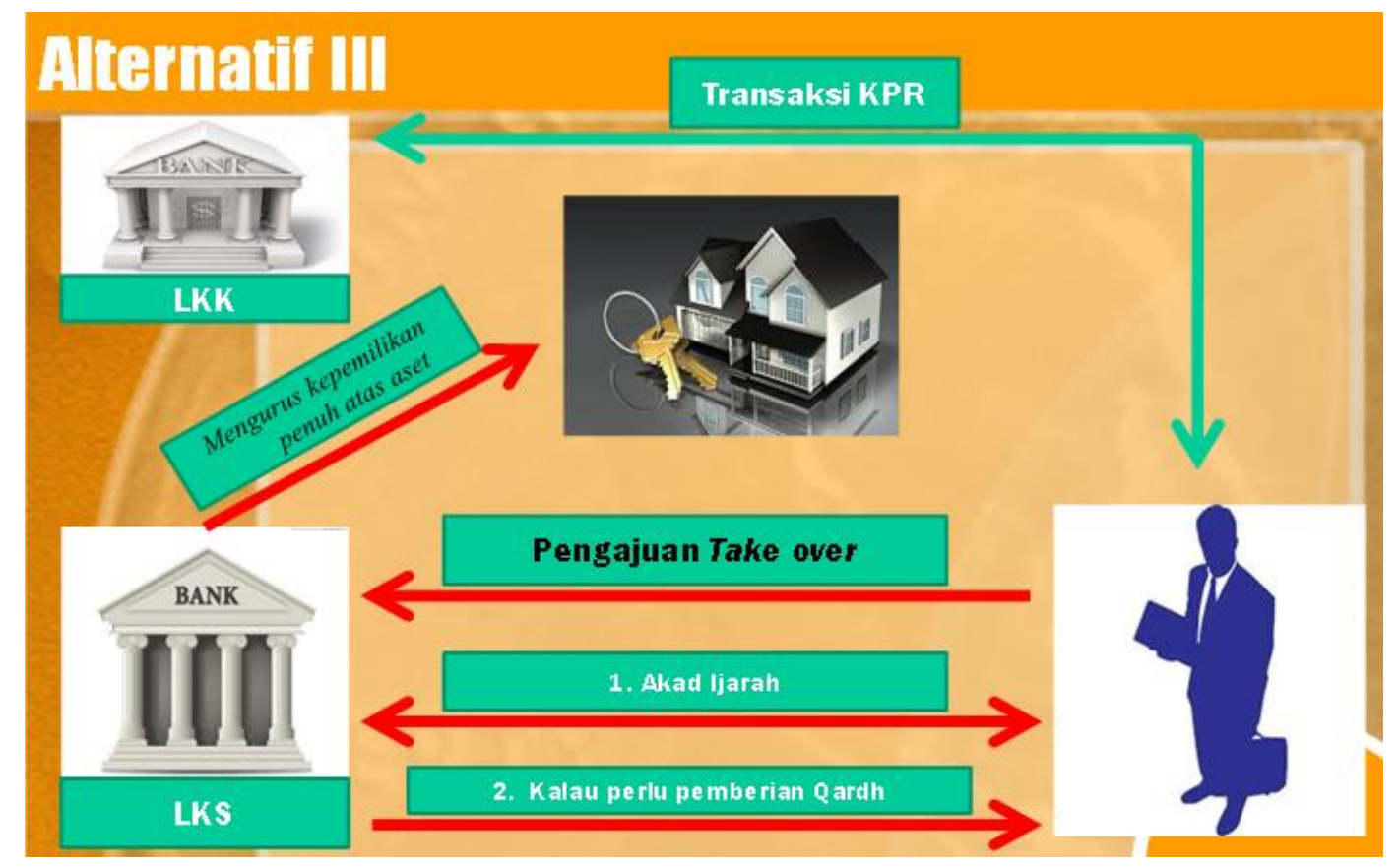

Gambar 3. Alternatif III untuk Akad Pengalihan Utang (Take Over)

\section{d. Alternatif VI}

Pada alternatif keempat ini yang digunakan adalah akad qardh dan al-ljarah alMuntahiyah bi al-Tamlik. Ilustrasinya adalah nasabah memiliki aset secara penuh dengan pemberian qardh dari LKS, sehingga nasabah dapat melunasi utangnya di LKK. Kemudian aset tersebut dijual kepada LKS dan dengan hasil penjualan itu nasabah melunasi qardh-nya kepada LKS. Aset tersebut kemudian disewa oleh nasabah dengan akad al-ljarah al-Muntahiyah bi al-Tamlik.

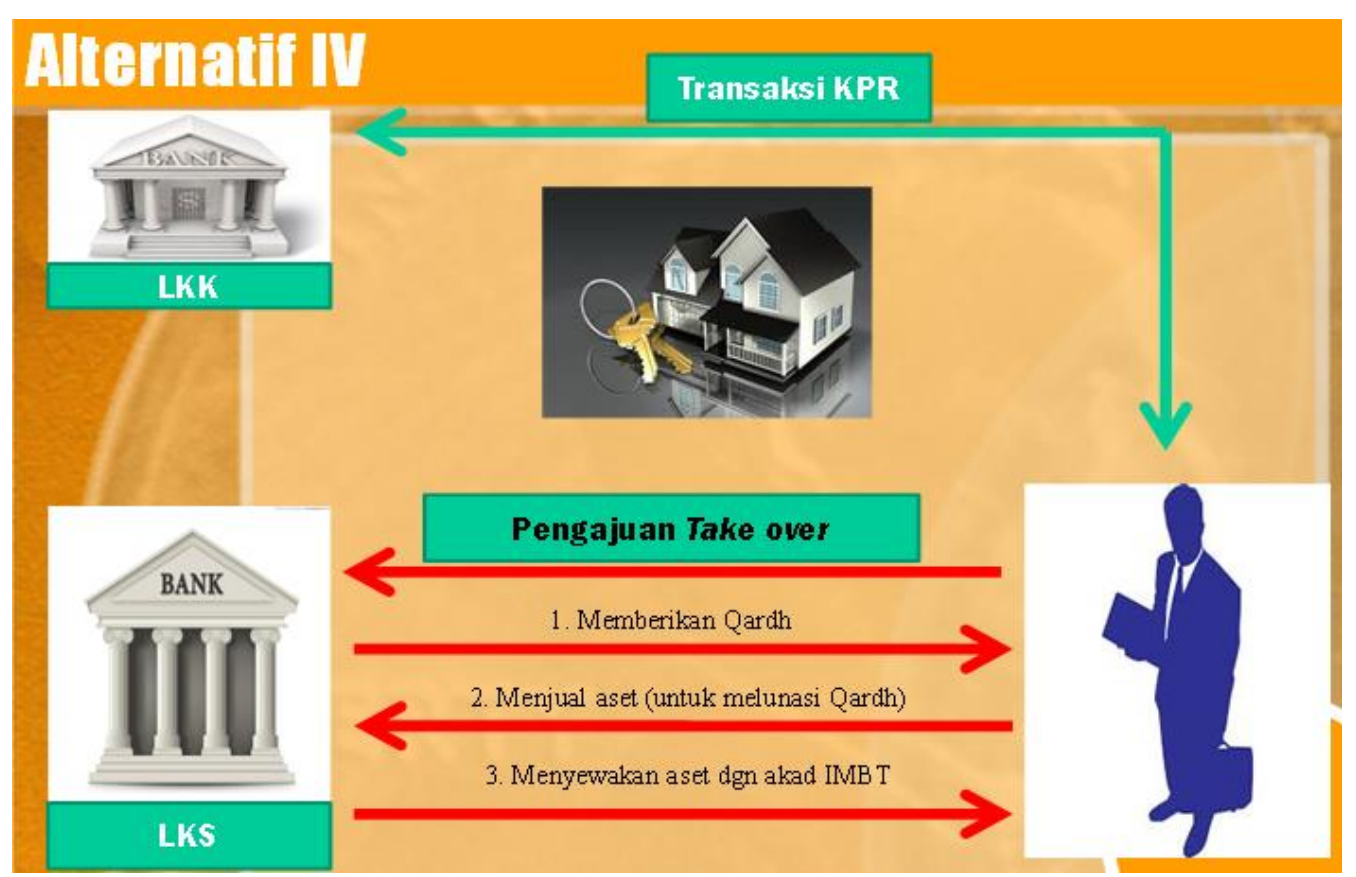

Gambar 4. Alternatif IV untuk Akad Pengalihan Utang (Take Over) 
Jurnal Ekonomi Syariah dan Hukum Ekonomi Syariah

Dari penjelasan di atas, maka take over dapat dikatakan hampir serupa dengan akad hiwalah muthlaqah yaitu pengalihan utang yang dimiliki oleh pihak pertama (muhil/pihak yang berutang) terhadap pihak kedua (muhal/pihak yang mengutangkan) kepada pihak ketiga (muhal alaih/orang yang membayarkan utang muhil) untuk dapat dilunasi utangnya tanpa dikatakan apakah muhal alaih mempunyai utang atau tidak kepada muhil. ${ }^{27}$

Pendapat beberapa mazhab tentang hiwalah muthlaqah ini diantaranya, Mazhab Hanafi yang memperbolehkan terjadinya hiwalah muthlaqah, mereka berpendapat bahwa jika akad hiwalah muthlaqah terjadi karena inisiatif pihak pertama, maka hak dan kewajiban antara pihak pertama dan pihak ketiga yang mereka tentukan ketika melakukan akad utang piutang sebelumnya masih tetap berlaku, khususnya ketika jumlah utang piutang antara ketiga pihak tidak sama. ${ }^{28}$ Sedangkan Mazhab Maliki, Syafi'i, dan Hambali hanya memperbolehkan terjadinya hawalah muqayyadah, yaitu pengalihan utang yang dimiliki oleh pihak pertama (muhil/pihak yang berutang) terhadap pihak kedua (muhal/pihak yang mengutangkan) kepada pihak ketiga (muhal alaih/orang yang membayarkan utang muhil) untuk dapat dilunasi utangnya dengan dikaitkan pada utang yang dimiliki muhal alaih kepada muhil. Jadi pihak ketiga harus memiliki utang pada pihak pertama agar akad hiwalah dapat berjalan. ${ }^{29}$

Adapun aplikasi akad hawalah aplikasi akad hawalah di lembaga keuangan syariah tidak dapat berdiri sendiri melainkan diwujudkan dalam kombinasi akad (hybrid contract). Model pembiayaan take over yang diterapkan merupakan bagian dari hybrid contract, yaitu secara akad adalah satu kesatuan akad yang tidak dapat dipisahkan yang terdiri dari beberapa akad. ${ }^{30}$

Jasa pengambilalihan utang nasabah di bank konvensional dapat dibedakan menjadi dua, yaitu jasa hiwalah apabila yang diambil alih hanya utang pokoknya saja dan jasa qardh apabila yang diambil alih utang pokok plus bunga. Pemberian jasa qardh pada pengambilalihan utang pokok nasabah ditambah bunganya dikarenakan penggunaan qardh tidak terbatas, termasuk untuk menalangi utang yang berbasis bunga. Sedangkan pemberian jasa hiwalah tidak bisa untuk menalangi utang yang berbasis bunga.

Utang yang di-take over oleh bank syariah dari bank konvensional adalah sisa angsuran nasabah di bank konvensional. Hal ini berarti bank syariah melakukan take

\footnotetext{
${ }^{27}$ Siti Nor Fatoni, Pengantar Ilmu Ekonomi, Dilengkapi Dasar-Dasar Ekonomi Islam, (Bandung: Pustaka Setia, 2014), h. 232

${ }^{28}$ M. Ali Hasan, Berbagai Macam Transaksi dalam Islam (Fiqh Muamalat), (Jakarta: PT RajaGrafindo Persada, 2003), h. 225

${ }^{29}$ Hiwalah adalah perpindahan hutang dari tanggungan (muhil) kepada muhal 'alaih (orang yang bertanggung jawab setelah hiwalah). Nurul Huda dan Mohamad Heykal, Lembaga Keuangan Islam: Tinjauan Teoretis dan Praktis, (Jakarta: Kencana Prenada, 2010), h.103

${ }^{30}$ Agustianto Mingka, 2013a. 10 Alasan Men-gapa Teori dan Praktik Hybrid Contracts Perlu Dipahami dalam Mengembangkan Perbankan dan Keuangan Syariah, 2013, www.agustiantocentre.com (diakses pada tanggal 1 Juni 2019)
} 
over atas utang pokok nasabah ditambah dengan keuntungan bank konvensional (bunga), maka pemberian jasa qardh lebih tepat untuk mengalihkan utang nasabah di bank konvensional ke bank syariah.

Menurut penulis berdasarkan Fatwa DSN No. 31/DSN-MUI/VI/2002 tentang Pengalihan Utang, maka dari keempat alternatif tersebut yang paling cocok untuk diterapkan dalam pembiayaan take over adalah alternatif ketiga yaitu menggunakan kombinasi akad ijarah dan qardh. Karena alternatif ketiga merupakan bentuk yang paling sederhana dan mudah untuk diimplementasikan. Namun dengan tetap memperhatikan bahwa besarnya ujrah ditentukan berdasarkan pengeluaran riil, bukan pada besarnya utang yang diberikan oleh LKS.

\section{Penutup}

Berdasarkan pembahasan tersebut, hasil penelitian menunjukkan bahwa pemberian jasa qardh pada pengambilalihan utang pokok nasabah ditambah bunganya dikarenakan penggunaan qardh tidak terbatas, termasuk untuk menalangi utang yang berbasis bunga, sehingga pemberian jasa qardh lebih tepat untuk mengalihkan utang nasabah di bank konvensional ke bank syariah. Berdasarkan hasil analisis terhadap Fatwa Dewan Syariah Nasional Nomor 31/DSNMUI/VI/2002, maka alternatif yang paling cocok untuk diterapkan dalam pembiayaan take over adalah alternatif ketiga yaitu menggunakan kombinasi akad ijarah dan qardh. Karena alternatif ketiga merupakan bentuk yang paling sederhana dan mudah untuk diimplementasikan. Namun dengan tetap memperhatikan bahwa besarnya ujrah ditentukan berdasarkan pengeluaran riil, bukan pada besarnya utang yang diberikan oleh LKS.

\section{DAFTAR PUSTAKA}

Abdi, Muhammad Nor, Praktek Al-Qardh di Perbankan Syariah, https://muhammadnorabdi.wordpress.com/2011/08/06/19/. (20 Januari 2019).

Anggraini, Juwita, dan Siti Mardiah, Analisis Kinerja Pembiayaan Take Over Pada BTN Syariah Di Tahun 2014-2015, Jurnal Finance, Vol.2 No.1, 2016

Anshori, Abdul Ghofur, Pokok-pokok Hukum Perjanjian Islam di Indonesia, Yogyakarta: Citra Media, 2006

Antonio, Muhammad Syafi'i, Bank Syariah: Dari Teori Ke Praktik, Jakarta: Gema Insani Press, 2001

Departemen Agama RI, Al-Qur'an dan Terjemahnya, Bandung: Diponegoro, 2008

Dewan Syariah Nasional Majelis Ulama Indonesia, Himpunan Fatwa Dewan Syariah Nasional, Jakarta: Gaung Persada Press, 2012 
AL-IQTISHADIYAH

Jurnal Ekonomi Syariah dan Hukum Ekonomi Syariah

Dineey, Anggun, Take Over Syariah, http://anggundineey17.blogspot.com/2012/12/bab-i-pendahuluan-a.html. (25 Februari 2015).

Fatoni, Siti Nor, Pengantar Ilmu Ekonomi, Dilengkapi Dasar-Dasar Ekonomi Islam, Bandung: Pustaka Setia, 2014

Firdaus, Rahmat, dan Maya Arianti, Manajemen Perkreditan Bank Umum: Teori, Masalah, Kebijakan, dan Aplikasi Lengkap dengan Analisis Kredit, Bandung: Alvabeta, 2004

Fitriani, Dhaifina, Griya Take Over Dalam Perbankan Syariah (Studi Kasus PT. Bank BNI Syari'ah Kantor Cabang Yogyakarta), Jurnal Az Zarqa', Vol.12 No.1, 2020

Hasan, M. Ali, Berbagai Macam Transaksi dalam Islam (Fiqh Muamalat), Jakarta: PT RajaGrafindo Persada, 2003

Hidayat, Muhammad Rifqi, dan Parman Komarudin. "Klausul Overmacht dalam Akad Murabahah di Perbankan Syariah." Al-Iqtishadiyah: Ekonomi Syariah dan Hukum Ekonomi Syariah 3, no. 1 (2017): 36-50.

Huda, Nurul, dan Mohamad Heykal, Lembaga Keuangan Islam: Tinjauan Teoretis danPraktis, Jakarta: Kencana Prenada, 2010

K. Muda, Ahmad Antoni, Kamus Lengkap Ekonomi, Jakarta: Gitamedia Press, 2003

Karim, Adiwarman A., Bank Islam: Analisis Fiqih dan Keuangan, Jakarta: RajaGrafindo, 2011

M. Echols, John, dan Hassan Shadily, Kamus Inggris Indonesia, Jakarta: PT. Gramedia Pustaka Utama, 1990

Majelis Ulama Indonesia, Himpunan Fatwa Keuangan Syariah; Dewan Syariah Nasional MUI, Jakarta: Erlangga, 2014

Mingka, Agustianto, 10 Alasan Men-gapa Teori dan Praktik Hybrid Contracts Perlu Dipahami dalam Mengembangkan Perbankan dan Keuangan Syariah. www.agustiantocentre.com, 2013

Muhamad, Manajemen Dana Bank Syariah, Jakarta: Rajawali Pers, 2015

Nurhayati, Sri; Wasilah, Akuntansi Syariah di Indonesia Edisi 3, Jakarta: Salemba Empat, 2013

Rochaety, Ety, dan Ratih Tresnati, Kamus Istilah Ekonomi, Jakarta: PT. Bumi Askara, 2005

Saraswati, Distie, dan Syamsul Hidayat, Implementasi Hybrid Contract Pada Take Over Pembiayaan Hunian Syariah Dari Bank Konvensional Ke Bank Syariah Dalam Perspektif Hukum Islam, Jurnal Jurisprudence, Vol.7 No.1, 2017

T. Guritno, Kamus Perbankan dan Bisnis, Yogyakarta: UGM Press, 1996 
Zaky, Achmad, Analisis Alternatif Pembiayaan Take Over Berdasarkan Prinsip Syariah (Hawalah), Jurnal Ekonomi, Manajemen, dan Akuntansi Islam (IMANENSI), Vol.1 No.2, 2014

Zuhri, Muh, Riba dalam Al-Qur'an dan Masalah Perbankan: Sebuah Tilikan Antisipasi, Jakarta: PT RajaGrafindo Persada, 1996

Zulkifli, Sunarto, Panduan Praktis Transaksi Perbankan Syariah, Jakarta: Zikrul Hakim, 2003 